International Journal of Engineering \& Technology, $7(4.34)(2018) 201-203$
SPC
Website: www.sciencepubco.com/index.php/IJET
Research paper

\title{
Corporate Governance Mechanism, Company Size Financial Performance and Sustainability Reporting
}

\author{
Andhika Ligar Hardika*, Daniel T. H. Manurung, Yati Mulyati \\ Faculty of Economics University of Widyatama, Bandung, West Java, Indonesia \\ *Corresponding author E-mail: Andika.ligar@widyatama.ac.id
}

\begin{abstract}
The importance of sustainability reporting for companies to be able to know the role of the company in disclosing social responsibility and the implementation of corporate sustainability as a manifestation of corporate governance mechanisms, company size and financial performance. This study uses a stratified random sampling method for companies that have revealed sustainability reports and those that do not disclose sustainability reports. The research method uses logistic regression, with a sample of 13 non-financial companies listed on the Indonesia Stock Exchange. Based on the results obtained, it can be seen that the mechanism of corporate governance consisting of independent commissioner variables has a negative influence on sustainability reporting, institutional ownership variables have a positive influence on sustainability reporting, managerial ownership variables have a negative influence on sustainability reporting, audit committee variables have a negative effect on sustainability reporting, the variable size of the company gives a negative influence on sustainability reporting, and financial performance variables which are leverage variables have a negative influence on sustainability reporting.
\end{abstract}

Keywords: Independent Commissioners; Institutional Ownership; Managerial Ownership; Audit Committee; Company Size; Leverage; Sustainability Report.

\section{Introduction}

Sustainability reporting application activity is also associated with the regulation of social and environmental responsibility in the Law of the Republic of Indonesia No. 40 the Year 2007 regarding Limited Liability Company of section 74 in paragraph 1, the Act states that "The company that runs business activities in the field and or related to the natural resources required to implement social and environmental responsibility". Law of the Republic of Indonesia Number 25 the Year 2007 on Investment Article 15 (b) states that "Every investor is obliged to implement corporate social responsibility". In these regulations explain if the company does not perform the obligation, will be penalised in accordance legislation. This means that the Indonesian government already requires social and environmental responsibility of companies. Therefore, the law became one impetus companies in Indonesia to implement social and environmental responsibility, then express it in a sustainability report.

The participation of companies in the sustainability of development is very important, as part of keeping the surrounding environment. Companies are required in order to understand and contribute to the sustainability of life of the surrounding environment. The impact of sustainable development provides a significant value contribution to society and the environment. Some of the cases contained in the company's activities that do not see the surrounding environment such as in the case of PT. Lapindo Brantas which causes damage to the surrounding environment as a result of mudflow in 2010, the case of PT. Tin in Bangka Belitung, Case PT. Indo Rayon was due to waste disposal as well as the case of PT. Freeport Indonesia related to industrial waste disposal companies that cause environmental damage. The cases occurred in Indonesia as a form that the company only wants profit alone without looking at aspects of society and the environment.

Research on the mechanisms of corporate governance and corporate characteristics on Sustainability Reporting is still not widely practiced in Indonesia so by doing this research may provide valuable insight into the company of the importance of sustainability reporting. Some research on corporate governance ever undertaken in Indonesia. Another study conducted by [14] with the aim of study to determine differences in the characteristics of companies (profitability, liquidity, leverage, activity, company size) and corporate governance (audit committees, the board of directors, governance committee) of companies issuing the Sustainability Report that are not issued. The results showed that except for leverage, all the characteristics of the company and corporate governance mechanisms differ significantly between the company issuing the Sustainability Report with a no. Furthermore, there is a positive effect caused by the variable profitability, size of the company, the board of directors and audit committee. While variables such as liquidity, leverage, activity, and governance committee do not give effect to the disclosure Sustainability Report. In [15] GCG mechanism would be useful in regulating and controlling the company to create added value for all stakeholders. To support this, GCG implementation must be supported with the corporate governance structure consists of the principal organs, namely the General Meeting of Shareholders (RUPS), the Board of Directors, and the Board of Commissioners. As well as the organs of other companies that help the realization of good governance, corporate secretarial, audit committee, and other committees that assist the implementation of GCG. While research [2] showed that the variables of the audit committee, governance committee and leverage positive effect on the disclosure Sustainability Report temporary variables independent board, managerial 
ownership and profitability do not affect the disclosure Sustainability Report.

Based on the background that has been stated previously, the researchers intend to conduct this study as a reference and a reference to determine the role and mechanisms for corporate governance, financial performance and the size of the company towards Sustainability Reporting.

\section{Literature Review}

Corporate governance mechanism is a procedure, and a clear relationship between the parties decided the parties conducting the control or supervision of the decision. According to [9], good corporate governance mechanisms classified into external and internal mechanisms.

Independent of commissioners-Independent board is a board that perform supervisory tasks on the management of the company's performance. Board size is the number of commissioners appointed, duty, and responsibility to supervise and advise the board of directors such as in research [1, 11-12]. Calculation formula with the number of board meetings during the period.

H1: BOC affect the Sustainability Report

Institutional ownership-High level of profitability in the company will increase the competitiveness between companies. A high level of profit that would signal the company's growth in the future. The company's growth requires more extensive disclosures in meeting the information needs according to the needs of each user $[1,14]$. According to $[1,4,6]$ suggests that the company's risk, trading volume, concentrated ownership and foreign ownership affect the environmental disclosure. Based on the assumption that foreign countries tend to pay more attention to social activities such as reporting Sustainability Report. The formula for calculation of foreign ownership with the proportion of foreign-owned shares divided by the number of shares issued.

H2: Institutional Ownership affect the Sustainability Report

Managerial ownership is a large number of shares owned by the management of the company's total shares outstanding. Managerial ownership is measured in the percentage of shares owned by management (in this case the board of directors, and the parties directly involved in the decision-making companies) by the number of shares issued, as in the study [1, 12].

H3: Managerial Ownership affect the Sustainability Report

Audit committee-The audit committee was formed to examine the financial liability of directors of the company to its shareholders. The audit committee has audited the financial statements can be trusted if the audit committee has competence and independence. Internal control system and the effectiveness of internal and external audit assignments. The existence of the audit committee can be a useful tool to conduct surveillance mechanism to reduce agency costs, improve internal control and will improve the quality of corporate disclosure [11-12]. In this study, the audit committee is proxied by the number of audit committee meetings within a year. H4: Audit Committee affect the Sustainability Report

Company size-According to $[7,11]$ from several studies, the size of the company can be measured by the number of employees, total assets, or sales volume ranking index. This study uses total assets to measure variables company size. Variable size is presented in the form of natural logarithms because of the value and distribution, which is higher than the other variables.

H5: Size effect on the Company's Sustainability Report

Leverage-It is supported by a study [8] in [11, 14], which states that companies with a high leverage ratio that will bear monitoring costs are too high. Companies will tend to incur greater in the process of information collection and management in order to create reports, so companies will choose to reduce the level of disclosure, especially voluntary as SR. In this study, the indicators used to measure the level of leverage is Debt to Equity Ratio (DER).

H6: Leverage effect on Sustainability Report

\section{Methodology}

This study uses a stratified random sampling method for companies that have revealed sustainability reports and that do not disclose the sustainability report and annual financial statements of companies listed on the Indonesia Stock Exchange with the study period 2014-2015. Based on the stratified random sampling method, the number of sample companies that revealed sustainability reports were 13 companies. The regression used in this study is the logistic regression as a hypothesis test and analysis tool in the study using logistic regression method.

\section{Results and Discussion}

\subsection{Regression Model}

This research using logistic regression analysis. Logistic regression does not require normality test on the independent variables as independent variables is a mix between continuous variables (metric) and categorical (non-metric) [5].

\subsection{Regression Logistic Model}

Chi-square value table for the DF 6 (the number of independent variables - 1) at the 0.05 significance rate of 12.5916 . Because the chi-square value of Hosmer and Lemeshow $3.858<12.5916$ or significance value of $0696(>0.05)$, so accept H0 indicating that the model is acceptable and hypothesis testing can be done because there are significant differences between the models with observations value.

Table 1: The goodness of Fit test

\begin{tabular}{|c|c|c|c|}
\hline \multicolumn{4}{|c|}{ Hosmer and Lemeshow Test } \\
\hline Step & Chi-Square & df & Sig \\
\hline 1 & 3.858 & 6 & .696 \\
\hline
\end{tabular}

\subsection{Due Diligence Overall Fit Model Test}

Table 2 gives the conclusion that the value of -2LL block number $=0<$ value block number $=1$, then the value of the initial $-2 \mathrm{LL}$ amounted to 11.014. Once included 6 independent variables, then the value of the final -2LL decreased so that it can be concluded that the regression model is both better.

Table 2: Comparison value $-2 \log L$ beginning and $-2 \log L$ end \begin{tabular}{l|l}
-2 LogL beginning (Block number $=0)$ & 17,392
\end{tabular} \begin{tabular}{l|r}
$-2 \operatorname{LogL}$ End $($ Block number $=1)$ & 11,014
\end{tabular}

Table 3 Value Nagelkerke R Square of 0505 and Cox and Snell R Square 0347 which showed that the ability of independent variables in explaining the dependent variable is equal to 0505 , or $50.5 \%$, and there is a $100 \%-50.5 \%=49.5 \%$ other factors beyond models that explain the dependent variable.

Table 3: Cox and Snell's R square and Nagelkereke's R square

\begin{tabular}{|c|c|c|c|}
\hline Step & -2 Log Likelihood & $\begin{array}{c}\text { Cox and Snell R } \\
\text { Square }\end{array}$ & Nagelkerke R Square \\
\hline 1 & $11.014^{\mathrm{a}}$ & .347 & .505 \\
\hline a. & $\begin{array}{l}\text { Estimation terminated at literation number } \\
\text { changed by less than } 0.01\end{array}$ & because parameter \\
\hline
\end{tabular}

4.4. Significance testing Regression Coefficients 
Table 4: Significance testing and interpretation

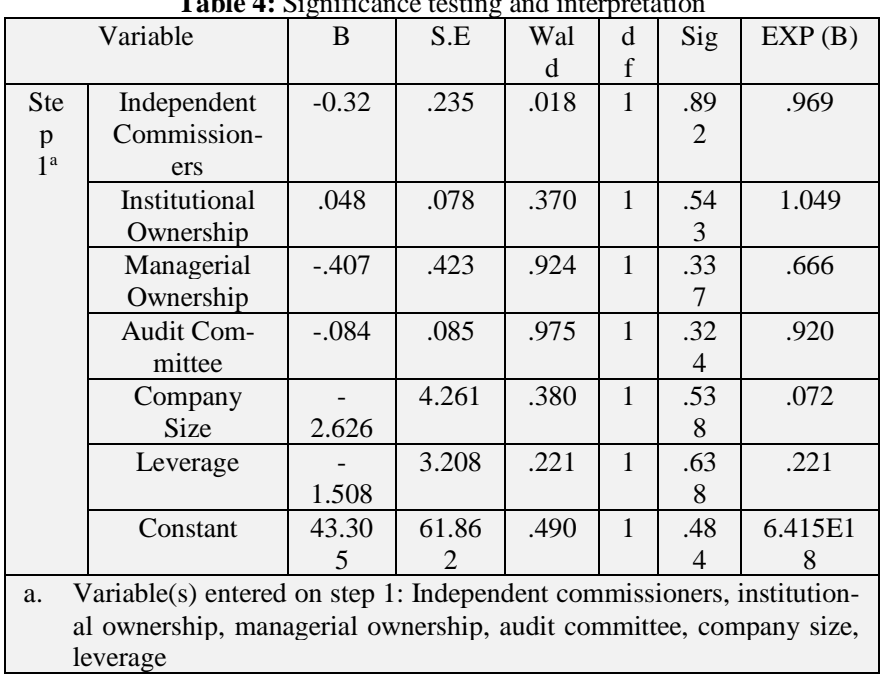

a. Independent commissioner variable with B value of natural logarithm is $.969=-.032$. The value of B Logarithm is negative, so the independent commissioner has a negative effect on sustainability reporting. Results of this research is in line with $[1,12,15]$ said that independent directors do not affect the sustainability report because they cannot influence the decisionmaking process on the company's activities and meetings conducted by the board of commissioners less effective and not in accordance with the provisions applicable to the implementation of Corporate Governance.

b. Institutional ownership variable with $B$ value of natural logarithm is $1,049=.048$. The value of B logarithms is positive, so institutional ownership has a positive effect on sustainability reporting. This study is not in line with the [10, 15] says that there is a negative relationship between institutional stock ownership with voluntary disclosure, meaning that the higher shareholdings by institutions, it will reduce the level of voluntary disclosure made by the company.

c. Managerial ownership variable with a B Logarithm value of $.666=-.407$. The value of B Logarithm is negative, so managerial ownership has a negative effect on sustainability reporting. This study is in line with [1-2, 15] says that there is much management that does not have a stake in a company that is managed or own shares however small that cause has not been able to maximize the value of companies in the sustainability report.

d. Audit committee with B Logarithm value of .920 = .084. The value of B logarithms is negative, so the audit committee has a negative effect on sustainability reporting. This study is in line with $[11,15]$ says that the existence of an audit committee helps ensure the disclosure and control system to run properly.

e. $\quad$ Company size with B Logarithm value of $.072=2.626$.

The value of B logarithm is negative, so the size of the company has a negative effect on sustainability reporting. This study is not in line with the [13-15] says that the larger companies will tend to eat disclosure broader sustainability report.

f.Leverage with B Logarithm value of .221 = -1.508. The value of B Logarithm is negated, so leverage has a negative effect on sustainability reporting. This study is in line with [3, 11, 14] said that the higher the leverage the more likely the company will be in violation of the loan agreement, so the company will try to report higher earnings were done one way to reduce costs, including costs for social disclose information.

\section{Conclusion}

Based on the results obtained, it can be seen that the mechanism of corporate governance consisting of independent commissioner variables has a negative influence on sustainability reporting, in- stitutional ownership variables have a positive influence on sustainability reporting, managerial ownership variables have a negative influence on sustainability reporting, audit committee variables have a negative effect on sustainability reporting, the variable size of the company gives a negative influence on sustainability reporting, and financial performance variables which are leverage variables have a negative influence on sustainability reporting. This study states that sustainability reporting conducted by listed non-financial companies in the Indonesian stock exchange is very important because it is a form of corporate responsibility for the environment in the form of company operations so that the need for corporate governance to be better in sustainability reporting, the company size variable, as an indicator in determining the importance of sustainability reporting is seen from the size of the company, and also leverage as an indicator of financial performance is the number of companies that are unable to carry out sustainability reporting due to the large costs in sustainability reporting rather than implementing programs corporate responsibility for the community and corporate environment. The importance of sustainability reporting as the basis of corporate reporting and indicators in the implementation of corporate responsibility programs and also as a basis for attracting investor interest to the company and public trust in the company's operations.

\section{References}

[1] Adhipradana F, Daljono. Pengaruh kinerja keuangan, ukuran perusahaan dan corporate governance terhadap pengungkapan sustainability report. Diponegoro Journal of Accounting, 2014, 3(1): 112.

[2] Aniktia R, Khafid M. Pengaruh mekanisme good corporate governance dan kinerja keuangan terhadap pengungkapan sustainability reporting. Accounting Analysis Journal, 2015, 4(3): 1-10.

[3] Belkaoui A, Karpik PG. (1989). Determinants of the corporate decision to disclose social information. Accounting, Auditing and Accountability Journal, 2(1): 36-51.

[4] Cormier D, Magnan M, \& Van Velthoven B. Environmental disclosure quality in large German companies: Economic incentives, public pressures or institutional conditions? European Accounting Review, 2005, 14(1): 3-39.

[5] Ghozali I. (2011). Aplikasi Analisis Multivariate Dengan Program IBM dan SPSS. In Aplikasi Analisis Multivariate Dengan Program IBM SPSS 19

[6] Ghozali, I., \& Chairiri, A. (2007). Teori Akuntansi. Universitas Diponegoro.

[7] Hackston, D., \& Milne, M. J. (1996). Some Determinants of Social and Environmental Disclosures in New Zealand Companies. Accounting, Auditing \& Accountability Journal, 9(1), 77-108.

[8] Jensen, C., \& Meckling, H. (1976). Theory of the Firm: Managerial Behavior, Agency Costs and Ownership Structure. Journal of Financial Economics, 3, 305-360.

[9] Man, C., Hong, K., \& Wong, B. (2013). Corporate Governance And Earnings Management : A survey of Literature. The Journal of Applied Business Research, 29(2), 391-418.

[10] Matoussi, H., \& Chakroun, R. (2009). Board Composition, Ownership Structure and Voluntary Disclosure In Annual Reports Evidence From Tunisia. International Journal of Business and Behavioural Sciences, $1-28$.

[11] Putri Yustia Sari, M., \& Marsono. (2013). Pengaruh Kinerja Keuangan, Ukuran Perusahaan dan Corporate Governance Terhadap Pengungkapan Sustainabillitty Report. Diponegoro Journal of Accounting, 2(2011), 1 10.

[12] Roshima, S., Yuserrie, H. Z., \& Hasnah, H. (2009). The Relationship Between Corporate Social Responsibility Disclosure and Corporate Governance Characteristics in Malaysian public listed companies. Social Responsibility Journal, 5(2), 212-226.

[13] Sembiring, E. R. (2005). Karakteristik Perusahaan dan Pengungkapan Tanggung Jawab Sosial : Study pada Perusahaan yang Tercatat di Bursa Efek Jakarta. Simposium Nasional Akuntansi VIII. Solo, (September), $15-16$.

[14] Suryono, H., \& Prastiwi, A. (2011). Pengaruh Karakteristik Perusahaan Dan Corporate Governance $(\mathrm{Cg})$ Terhadap Praktik Pengungkapan Sustainability Report (SR) ( Studi Pada Perusahaan - Perusahaan yang Listed (Go-Public) di Bursa Efek Indonesia (BEI) Periode 2007 - 2009 ). Simposium Nasional Akuntansi XIV Aceh 2011, 21-22.

[15] Waryanto. (2010). Pengaruh Karakteristik Good Corporate Governance (Gcg) Terhadap Luas Pengungkapan Corporate Social Responsbility (CSR) Di Indonesia (Skripsi). Skripsi. Semarang. 